\title{
Service quality in a post-crisis context: emotional effects and behaviours
}

\author{
Manuel Idrovo Arguello \\ Department of Marketing, Universitat Jaume I, Castellón, Spain, and \\ Diego Monferrer Tirado and Marta Estrada Guillén \\ Department of Business Administration and Marketing, \\ Universitat Jaume I, Castellón, Spain
}

Service quality in a post-crisis

context

Received 4 February 2019

Revised 11 April 2019

12 May 2019

Accepted 23 May 2019

\begin{abstract}
Purpose - The purpose of this paper is to analyse the influence of service quality dimensions as determinants of the emotional and relational behaviours experienced by the client in bank branches in the post-crisis context experienced by Spanish financial institutions.

Design/methodology/approach - Data taken from a total of 1,125 customers were analysed through structural equations modelling (EQS6.1) to test the relationships of the proposed model's variables.

Findings - The results support the hypotheses stated, with the exception of the influence of a service quality dimension (servicescape) on emotions during the service. In fact, the dimensions of the service quality of an intangible nature (personnel, outcome and social) are determinants of the positive emotions and relational behaviours of clients around the service provided by the branches. For its part, servicescape quality, of a more tangible nature, exerts indirect influence on the other dimensions that compose the quality of service.

Practical implications - This paper provides senior bank executives established evidence on the degree of influence of the different dimensions in relation to the quality of service in the bank branch. Furthermore, it emphasises the importance of emotional factors during service as essential elements in strengthening customer-staff relationships under a non-transactional dynamic.

Originality/value - This paper has adopted an analytical holistic, theoretical and empirical perspective on the impact of the different dimensions of service quality (servicescape, personnel, outcome and social) as well as to the emotions experienced by banking customers during services and its lasting effect on customer engagement and customer advocacy.
\end{abstract}

Keywords Service quality, Advocacy, Engagement, Emotions, Banking industry

Paper type Research paper

\section{Introduction}

The financial crisis of the early twenty-first century has negatively impacted many commercial sectors around the world, including Spain's banking and financial industry (Monferrer et al., 2016, 2019; Estrada et al., 2018; Moliner et al., 2018, 2019). Despite the fact that the aftermath of the financial crisis has consistently remained a common theme in newspapers all over the world (bank rescue, the evolution of premium risk, qualification of sovereign debt), there has been less focus on its impact on a micro-economic scale (Monferrer et al., 2016). The drastic decline in credit to families and small entrepreneurs, the payment of excessive commissions, preferential participation scandals and the harsh banking restructuring policies, among others, have challenged the strength and honesty of the banking sector (Bennett and Kottasz, 2012; Hansen, 2014; Johnson and Peterson, 2014; Monferrer et al., 2016). All of this has provoked an emotional

(C) Manuel Idrovo Arguello, Diego Monferrer Tirado and Marta Estrada Guillén. Published by Emerald Publishing Limited. This article is published under the Creative Commons Attribution (CC BY 4.0) licence. Anyone may reproduce, distribute, translate and create derivative works of this article (for both commercial and non-commercial purposes), subject to full attribution to the original publication and authors. The full terms of this licence may be seen at http://creativecommons.org/licences/by/4.0/legalcode

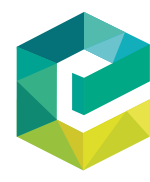

International Journal of Bank Marketing Vol. 38 No. 1,2020 pp. $175-198$

Emerald Publishing Limited $0265-2323$ DOI 10.1108/IJBM-02-2019-0045 
IJBM

38,1

environment that has conditioned more than ever the relationship of the clients with their banks, increasing the indices of mistrust and the number of disloyalties (Estrada $e t$ al., 2018; Moliner et al., 2019).

Following such a turbulent period, the need to understand what factors are most decisive in maintaining satisfactory and lasting relationships with customers becomes a crucial challenge for Spanish banks (Strandberg et al., 2012; Ha et al., 2014; Marinkovic and Obradovic, 2015; Sayani, 2015; Zameer et al., 2015; Monferrer et al., 2016; Moliner et al., 2018).

This fact is even more relevant if we take into account the growing homogenisation of institutions in terms of the creation of products/services (Pérez and Rodríguez, 2012), which generates a need to reinvent the service and create a differentiated advantage in the face of competition (Kaura et al., 2015; Sayani, 2015).

Providing companies introduce new strategies and solutions to the financial sector that favour the improvement of their relationships with their clients, their business should benefit. In this regard, service literature tends to see service quality as a key construct when it comes to explaining the variables associated with the relationship quality (Strandberg et al., 2012; Kaura, 2013; Fatima and Razzaque, 2014; Kaura et al., 2015; Sayani, 2015; Monferrer et al., 2016). Therefore, the underlying premise is that the customer's evaluation with regard to the service quality offered by a service provider is determined by the affective responses from the latter (Ha et al., 2014).

However, a comprehensive review of the existing reports and literature in this field of study indicates that: the existing research focuses, almost exclusively, on positive relationships between the company and the client; the proposed causal models tend to focus attention on specific dimensions of service quality, without adopting an holistic approach to this concept; there is no evidence of integration of social conditions within the dimensions of service quality; the empirical studies are limited to the direct causal relationships of the dimensions of the service quality on other consequential factors, without considering any interrelation between the dimensions themselves. These aspects result in important gaps and limitations that condition the current state of affairs in this field. In response to those, and in trying to complement the existing literature to date, this study focuses on an alternative approach when analysing this hypothesis.

First of all, this study is framed on a post-crisis market context where the relationship with the customers and their subsequent behaviours were negatively affected (Monferrer et al., 2016, 2019; Estrada et al., 2018; Moliner et al., 2018, 2019). In these conditions, the client adopts a demanding and attentive stance in his evaluation of the practices of his institutes (Pérez and Rodríguez, 2012; Ha et al., 2014), offering a context of analysis of maximum interest for the investigation of the influences between the service quality and the subsequent effect it has on their relationship with the staff.

Second, our research adopts a holistic and integrative approach that considers the traditional dimensions of service quality including a new one that is the social quality, to identify which quality factors of service are the most valued by the clients contributing in this way to the generation of service experiences by the banks in the context of their emotionally positive branches that contribute to reinforcing the relational behaviors developed by them (Sayani, 2015; Monferrer et al., 2016; Pansari and Kumar, 2017; Moliner et al., 2019).

As expressed by Ha et al. (2014), it is necessary to consider collectively all the elements of value that are involved in the provision of customer service, since the evaluation made by the clients regarding this will not only depend on any one particular quality element. Therefore, models that only include basic quality dimensions provide an incomplete picture of the determinants of the overall service assessment (García et al., 2005; Ha et al., 2014; Monferrer et al., 2016). 
Third, according to literature, the integration of social quality is a major contributory factor to the quality of service for clients. At the basis of literature, we find studies examining the link between social responsibility initiatives and marketing results are, especially under the marketing perspective (Maignan and Ferrell, 2004; McDonald and Rundle, 2008; Liu et al., 2014), identifying various gaps to explore (Pérez and Rodríguez, 2012; Liu et al., 2014): despite the widespread adoption of socially responsible initiatives throughout the world banking community, there are no studies on the impact of social quality measures on the influence of clients behaviours throughout the service; and of existing empirical research, most focus on sectors associated with consumer goods. Thus, the growing social and ethical activity undertaken by banks in response to the negative public opinion generated by the sector, how banks may achieve a competitive customer edge in this socially responsible era with respect to the other traditional dimensions that make up the service quality is considered as a major question from an academic standpoint as well as a managerial one.

Finally, this study proposes completing the existing research around the construct of the service quality, not only under consideration of the direct causal effects of its different dimensions, but also through the analysis of the possible existence of correlations between them based on their distinct nature, mostly tangible and intangible (Monferrer et al., 2016; Wahlberg et al., 2016).

Taking all of these aspects into consideration, the aim of this work is to analyse relationships with the customers within the Spanish financial sector from a micro-economic and emotional perspective. In order to generate a broader theory, this paper proposes a model based on the reinforcement of the non-transactional emotional and relational linkages generated in the context of the branch between financial institutes and their clients (focussed primarily on the emotions experienced by the client during the service, their engagement and their advocacy), identifying and analysing the antecedent role set by the different factors that determine quality in the institute's service provision (outcome, personnel, servicescape and social qualities).

This paper opens with Section 2 defining service quality in the bank branch context. It follows with Sections $3-5$ by addressing the theoretical framework which provides the basis with the hypothesis of the model of effects. Then, Section 6 includes the study approach and research method used to test the model, with the analysis of results in Section 7. Finally, the main findings conclusions and implications are discussed in Section 8, and limitations and future lines of research related to this study are exposed in Section 9.

\section{Service quality in the bank branch context}

There is a consensus in the literature around defining the service quality as: "those features of products which meet customer needs and thereby provide customer satisfaction" (Juran and Godfrey, 1999). This definition stems from the difference between the perceived service and the service expected by the client as a result of the customer's consideration of a set of factors associated with it (Sayani, 2015; Zameer et al., 2015; Monferrer et al., 2016).

Despite the practical unanimity in accepting this interpretation, there is some controversy about the determinants of the service quality (Goplani, 2013; Monferrer et al., 2016). In fact, this view is supported by many academics in this field: the Nordic model (Grönroos, 1984) assesses the dimensions of the quality of service in terms of functional and technical quality; the three-component model (Rust and Oliver, 1994) focuses on variables such as service product, service delivery and service environment; the multilevel model (Dabholkar et al., 1996) presents a hierarchical vision dividing the service quality into three different levels, which are the general perceptions of the clients on the service quality, primary dimensions and sub-dimensions (Brady and Cronin, 2001); and the SERVQUAL model considers the quality perceived in the service as gaps between the client's
Service quality in a post-crisis context 
IJBM

38,1

178

expectations and perceptions in relation to five elements namely (Parasuraman et al., 1988): reliability or ability to provide the service; ability to respond or desire to help customers quickly; the physical facilities, equipment and appearance of the organisation; the ability to inspire customer confidence; and empathy or personalised service.

However, despite the efforts made from different perspectives and in very diverse sectors, there still remains a remarkable lack of agreement around the identification of the variables associated with the service quality currently (Goplani, 2013), as a growing number of authors gather in the context of the banking sector (Fatima and Razzaque, 2014; Sayani, 2015; Monferrer et al., 2016). This investigation uses Brady and Cronin's (2001) model as reference to the definition of service quality, which is explained as the sum of three types of fundamental quality factors in the provision of services of a financial institute: outcome, servicescape, and personnel qualities (Fatima and Razzaque, 2014; Sayani, 2015; Monferrer et al., 2016; Wang et al., 2016).

Additionally, we complete these three variables with the inclusion of the social quality, understood as the ethical behaviour of the company (García et al., 2005; McDonald and Rundle, 2008; Pérez and Rodríguez, 2012; Ha et al., 2014). Indeed, many institutes are already implementing social responsibility policies in order to increase the perception of service quality in their customers.

Following a period of progressive deterioration in the quality of the relationship between institutes and clients with the sacrifice of resources (the closing of branches, restructuring of the personnel, mergers, limitations of operations in the cashier, etc.), the lack of honesty (brake on financing, commissions and abusive clauses), and a loss of benevolence (nonrecourse debt, housing evictions, etc.), the extensive analysis of the background effects of the different dimensions that make up the quality of service becomes an essential challenge for both academics and managers (Miles et al., 2012; Fatima and Razzaque, 2014; Monferrer et al., 2016). On this basis, the next sections will try to develop the particular hypothesis that is derived from the service quality.

\section{Service quality as antecedent of emotions during the service}

There is a considerable discrepancy between scholars to determine the content of emotions. The most common classification differentiates between positive and negative emotions (Laros and Steenkamp, 2005). The main advantage of this classification is its simplicity and the assumption that it is an approximation of the client's attitude. However, its main disadvantage is that it does not detect very specific, relevant information about consumer sentiments (Bagozzi et al., 2016), which implies a loss of explanatory power in the behaviour model (Moliner et al., 2019).

After a compelling analysis of the concept in the context of marketing, the model proposed by Russell (1980) is the strongest due to its level of specificity and its applicability to a wide range of services and scenarios (Martin et al., 2008). This model argues that the best description of the interrelationship between the different types of emotions is by a spatial model of different affective components related to emotion defined as a combination of the pleasure degree and the degree of arousal (Moliner et al., 2019).

\subsection{Servicescape quality and emotions during the service}

Servicescape is known as the place where customers receive service by creating direct contact between customers and personnel (Booms and Bitner, 1981) and also a relevant area in the management and commercialisation of the service (Ha et al., 2014; Nilsson and Ballantyne, 2014; Monferrer et al., 2016).

A thorough examination of the literature gives allowance to identify generic variables' series applicable to the banking sector (Hooper et al., 2013; Ha et al., 2014; Nilsson and Ballantyne, 2014): environmental conditions are composed of intangible things such as 
temperature, lighting, smell, and sound; conditions of cleanliness present the control of dirt, which includes bad odours, dust and stains; and design conditions including elements being either functional or aesthetic with issues ranging from architectural design to the materials, the colours used in the decor and the spatial distribution of furniture and equipment.

According to its effects on the emotions experienced by the client, first, regarding environmental conditions, elements such as sound or smell are not only able to stimulate certain emotions and moods during the delivery of the service, but can also affect the buying behaviour itself (Harris and Ezeh, 2008; Nilsson and Ballantyne, 2014).

In reference to the conditions of cleanliness, due to the fact that the client understands that the maintenance of optimal levels of hygiene and cleanliness is not expensive and is easily controllable for the company, its austere non-compliance constitutes one of the most serious service failures experienced (Harris and Ezeh, 2008; Miles et al., 2012; Hooper et al., 2013).

Finally, regarding the design conditions, the materials used in the construction, decoration and floor covering, including the existing technological elements, represent an implicit communicative element used by the client known as an "information trail" that generates a correct behaviour within the environment where the service is provided and received (Bitner, 1992; Miles et al., 2012; Strandberg et al., 2012; Hooper et al., 2013; Ha et al., 2014; Nilsson and Ballantyne, 2014; Monferrer et al., 2016; Wang et al., 2016). More specifically, in a banking context, these conditions have an additional purpose associated with the confidentiality offered by the facilities, which is key to the perception of intimacy held by the client (Amin and Isa, 2008; Amin et al., 2013). Hence, it is assumed that:

H1. Customer perceived servicescape quality has a directly positive impact on the generation of positive emotions during the service at bank branches.

\subsection{Personnel quality and emotions during the service}

Personnel quality refers to the qualities that the personnel contribute to their work. The banking institutes have direct interaction with their clients through their branches, so the service quality can be perceived immediately and in situ based on the interactive process that takes place between the clients and the suppliers of the service (Strandberg et al., 2012; Marinkovic and Obradovic, 2015; Zameer et al., 2015; Wang et al., 2016; Estrada et al., 2018; Moliner et al., 2018).

With a thorough review of the literature, four main variables associated with personnel quality were identified (Harris and Ezeh, 2008; Kaura et al., 2015; Wahlberg et al., 2016): image conditions refer to the physical personnel characteristics, as well as attractiveness and presence, technical conditions cover service experience, derived from personnel's product/service knowledge; safety conditions involve personnel degree as a competent source; and empathy conditions contain personnel tendency and predisposition towards customers to satisfy needs during service.

The appearance of the personnel of the banking branches has a hidden message that imparts meaning through the language of the object, thus helping the clients to make judgments about the service before and after its consumption. Consequently, a pleasing physical demeanour through clean clothing and proper personal grooming would enhance the customer's emotional positivity towards service (Bitner, 1992; Kassim and Souiden, 2007). With regard to the technical conditions, a seminal form has been considered the most relevant criterion pointed out by customers in their relationship with service providers, since the intangibility associated with the services provided would accentuate the dependence of the customers on personnel to solve their problems (Harris and Ezeh, 2008; Tsoukatos and Mastrojianni, 2010). This fact would be clear in the banking context, where the service provided to the client is predominantly based around the customer and their savings.
Service quality in a post-crisis context 
IJBM

38,1

180

The security conditions linked to the projection of credibility by the banking supplier would influence the customer's positive attitudes towards the service (Harris and Ezeh, 2008).

Regarding the conditions of empathy, the emotional competence of the personnel (referring to the personalisation of the service, putting themselves in the place of the client) would make them feel recognised and treated as a unique person. It allows to develop a key mutual emotional bond in strengthening their relationships (Rajaobelina and Bergeron, 2009; Kaura, 2013; Fatima and Razzaque, 2014). Therefore, it can be assumed that:

H2. Customer perception of personnel quality has a directly positive impact on the generation of positive emotions during the service at bank branches.

\subsection{Outcome quality and emotions during the service}

Outcome quality refers to the effectiveness of the financial institution's service provision to its customers (Monferrer et al., 2016). It is concerned with, what the customer actually receives from the service transaction. The review carried out around the outcome quality allows us to identify the following conditions (Kaura, 2013; Kaura et al., 2015): service conditions related to the performance obtained in the same with respect to the expectation and its correct reception; product conditions associated with the convenience and variety of products/services offered; price conditions cover price perceptions and price fairness; and access conditions, which refers to the perceptions of waiting time favourably associated with the outcome quality perceptions.

According to the conditions of service, when service provision is efficient the client generates certain internal emotional barriers to change so that they perceive their relationship with the institute as ongoing (Amin and Isa, 2008).

In reference to product conditions, the expansion of the portfolio contributes to increasing opportunities to customise the package of services available according to the individual needs of the client (Tsoukatos and Mastrojianni, 2010), which have a positive effect on their emotional behaviour towards the bank (Strandberg et al., 2012).

With regard to price conditions, in the banking sector, where the price structure is complex and difficult to understand, transparency and fairness in pricing support the development of positive feelings towards the service provider (Strandberg et al., 2012; Kaura et al., 2015).

Finally, in relation to the conditions of access, the services are "time-dependent" and "time-important". If the banking service is effective and efficient, it will meet or even exceed the customer's expectations, affecting their emotions and strengthening their relationship with the bank (Amin and Isa, 2008; Sayani, 2015). Therefore, the following hypothesis is proposed:

H3. Customer perceived outcome quality has a directly positive impact on the generation of positive emotions during service in bank branches.

\subsection{Social quality and emotions during the service}

Social quality refers to social obligations that occur in customer service provision. (Maignan and Ferrell, 2004; McDonald and Rundle, 2008). Although this definition is commonly accepted, the nature and scope of these obligations remain uncertain and lack consensus (García et al., 2005).

On the one hand, we find a seminal current in which, according to Carroll (1991), the economic, legal, ethical and philanthropic responsibilities regulate the initiatives and social obligations of the company (García et al., 2005). However, the author himself (Schwartz and Carroll, 2003) and subsequent researchers (García et al., 2005) have 
demonstrated the limitations of this proposal, arguing that some of these dimensions are not easy to differentiate. On the other hand, we found authors who opted for the theory of sustainable development to justify the consideration of three components: economic, environmental and social (Bigné et al., 2005). However, in this model the environmental dimension takes on special relevance, making these forms of definition and measurement more appropriate in the study of sectors of activity with a greater environmental impact than the financial sector (Pérez and Rodríguez, 2012).

Trying to solve the problems raised in both perspectives, at the beginning of the twenty-first century aroses an approach based on interest groups (Decker, 2004). According to this proposal, the actions of social responsibility have to be classified preferentially according to those groups of interest that benefit the most from them (Pérez and Rodríguez, 2012). On this basis, Maignan and Ferrell (2004) argue that companies should only be responsible to company stakeholders (such as customers), while other authors argue that companies should be responsible to society as a whole (Kotler and Lee, 2005).

By adopting a conciliatory stance, our work advocates the consideration of both positions, so that initiatives include those that benefit customers more strongly and those that benefit society more strongly. On the one hand, the social quality would focus on the central stakeholder of the company (client), materialising in a relational orientation of the service provided to implement activities of the provision of benefits and assistance, which take the customer needs as a structural pillar (Ha et al., 2014). On the other hand, social quality would gather initiatives related to the environment (Pedersen, 2010) and society itself (Turker, 2009). In all types, the core value of social quality is not acting for profit alone, but for doing what is right (Liu et al., 2014).

About this conceptual framework, there is acceptance in recent literature that social programs influence service quality and customer emotions (Ha et al., 2014; Aranda and Sotomayor, 2016; García et al., 2016). After an emotionally negative period like the financial crisis of the late 2000 s, with serious social consequences and the generation of a generally negative public opinion in particular around the banking sector, the social and ethical activity undertaken by the banks should be rewarded by their clients, improving their behaviour and relational attitudes.

In terms of customer, organisations with a dominant culture based on proactive concern about clients make them feel that they receive incremental benefits in the provision of their services, significantly affecting the achievement of positive emotional attitudes by them (Ha et al., 2014).

With regard to society, the willingness of companies to implement social programs (corporate donations to social causes, participation in community activities, sponsorship of local events or environmental concerns, etc.) would achieve a positive effect on the emotional evaluations of their clients and the contingent effects linked to their contractual intentions (Maignan and Ferrell, 2004; Liu et al., 2014). Hence, the higher the social quality, the greater the emotions generated:

H4. Customer perceived social quality has a direct positive impact on the generation of positive emotions during the service at bank branches.

\section{The mediating role of engagement between emotions during service and customer advocacy}

In view of the growing importance of the role of social networking conversations, referrals and joint creation of services, some marketing researchers have focussed their attention on customer engagement as a way to explain the voluntary behaviours of clients that go beyond the transaction (non-transactional behaviours) (Brodie and Hollebeek, 2011).
Service quality in a post-crisis context 
IJBM

38,1

182

Customer engagement is a psychological state and an emotional link that occurs through the customer's interactive and creative experiences with the company (van Doorn et al., 2010; Brodie and Hollebeek, 2011). In other words, engaged customers experience a relationship associated with a strong emotional connection (Moliner et al., 2019).

The recent work of Pansari and Kumar (2017) will help us to understand the process of clients' engagement in the banking context. As we have assumed in the $H 1-H 4$, marketing actions around service quality would create awareness of what your bank offers based on the experience experienced in the office. These experiences would generate a certain level of emotion with respect to the institute (Cambra et al., 2016). If emotions are positive, they should be translated into certain behaviours aimed at strengthening the customer engagement to their institute, favouring the adoption of non-transactional behaviours in them (Chahal and Dutta, 2015; Moliner et al., 2019). Therefore, customers' actions would be the result of their level of engagement with the bank (Pansari and Kumar, 2017).

\subsection{Customer's emotions during the service and engagement}

The communicative Theory of Emotions (Oatley and Johnson, 1987) maintains that events are assessed in relation to the objectives of individuals. The positive emotion associated with achieving goals leads people to continue with their plan; in contrast, negative emotion is the result of the difficulties faced in carrying out the plan and the failure to achieve the desired objectives (Moliner et al., 2019). In this sense, in the experiences of banking service, emotions become an expected result or motivation for the client (Chou et al., 2016), having implications on their actions and behaviours.

Therefore, emotions come from tendencies in relation to the action. When the level of emotional participation with the product/service is high, an affective state arises in which the clients experience strong emotional reactions to the stimulus, which may influence their behaviours of engagement to the institute (Martin et al, 2008; van Doorn et al., 2010; Moliner et al., 2019). Hence, these arguments lead us to propose the following hypothesis:

H5. Emotions during service have a direct positive impact on customer engagement with the bank.

\subsection{Customer engagement and customer advocacy}

The concept of customer advocacy refers to the tendency of customers to offer a socially enthusiastic recommendation of service, brand or company (Chelminski and Coulter, 2011; Kumar et al., 2014), acting as a customer advocate (Fullerton, 2011; Moliner et al., 2019). Within the social behaviour of an individual (Batson, 1991), the client feels responsible for helping others and sharing information and opinions with them (Chelminski and Coulter, 2011).

Supporting ourselves in the definition of the concept, the assumption that customer advocacy would represent a client behaviour arising from the existence of engagement with his bank is already underlying (Moliner et al., 2019). Therefore, there should be a direct and positive causal relationship between the two (van Doorn et al., 2010). If customers identify and feel emotionally linked to their banks, they will want to act as advocates for them to give favourable recommendations, hoping that their branches will achieve the greatest success possible (Fullerton, 2011). Hence, the higher the customer engagement, the stronger the customer advocacy:

H6. Customer engagement has a direct positive impact on customer advocacy with the bank.

\section{Interrelationship between service quality dimensions}

Traditional literature has tended to study the effects of service quality dimensions on relationship quality in an isolated and direct way (Monferrer et al., 2016). Going one step 
forward, the consideration of an integrative model of different dimensions makes the analysis of the existence of an interrelationary effect between these dimensions possible.

Supporting ourselves in the definitions given to each of the dimensions considered, we note that while servicescape quality collects the most tangible essence of the service quality (Monferrer et al., 2016), the rest of the qualities (personnel, outcome and social) would represent intangible aspects in the provision of the banking service (Wahlberg et al., 2016).

In the services sector, as in the banking industry, there is a broad theoretical consensus in the classical literature about the determinant role of tangible elements in the service valuation by customers and their subsequent relationship with firms (Choudhury, 2014). The idea behind this assumption is that service companies try to make the purely intangible provision of their offer, tangible to provide more visible and tangible elements to the customer on the service he will receive. However, the empirical support of this assumed theoretical assumption is practically non-existent in the context of service quality. Trying to provide empirical support to this fundamental assumption, we propose a new block of hypotheses, which consider that the tangible elements of the service quality could reinforce the effect of the intangible elements (Monferrer et al., 2016).

Thus, the environmental, cleanliness and design conditions of the offices linked to servicescape quality would provide a positive first impression to the customer from the moment he walks through the door. A positive and high-quality immediate perception of these aspects of a more tangible nature would help the positive perception of office personnel (in terms of their condition in relation to image, technicality, security or empathy provision), on the condition that they characterise the service offered (defining elements of their products/services, price and access conditions), and even on the perception of the quality of their social interaction. In fact, the design and decorative elements used in the offices can keep and represent a high coherence between the activities and social actions undertaken by them, to the point of becoming indirectly imperative elements that would implicitly support the social quality of their banks (Aranda and Sotomayor, 2016). Therefore, we assumed that:

H7. Customer perceived servicescape quality reinforces positively personnel quality at bank branches.

H8. Customer perceived servicescape quality reinforces positively outcome quality at bank branches.

H9. Customer perceived servicescape quality reinforces positively social quality at bank branches.

In summary, this paper proposes a model of effects (Figure 1) which shows the role of the dimensions of service quality (servicescape, personnel, outcome and social qualities) on the emotions generated during the banking service $(H 1-H 4)$. These emotions will be determinants in two key relational variables of non-transactional nature such as customer engagement (H5) and customer advocacy (H6). In addition, as reflected in hypotheses $H 7-H 9$, our model raises the existence of interrelations between the dimensions of service quality, so that the more tangible nature (outcome quality) would have positive effects on those of a more intangible nature (servicescape, personnel, outcome and social qualities).

\section{Study approach and research method}

\subsection{Data collection and sample}

The researchers signed a collaboration agreement with one of the top five Spanish banks based on total assets according to Moody's international rating agency. This agreement allowed us to conduct interviews with clients for this study. The universe for the study was 530 bank branches in four Spanish provinces: Castellón, Valencia, Alicante and Murcia.
Service quality in a post-crisis context 
IJBM

38,1

\section{4}

Figure 1.

Model of effects

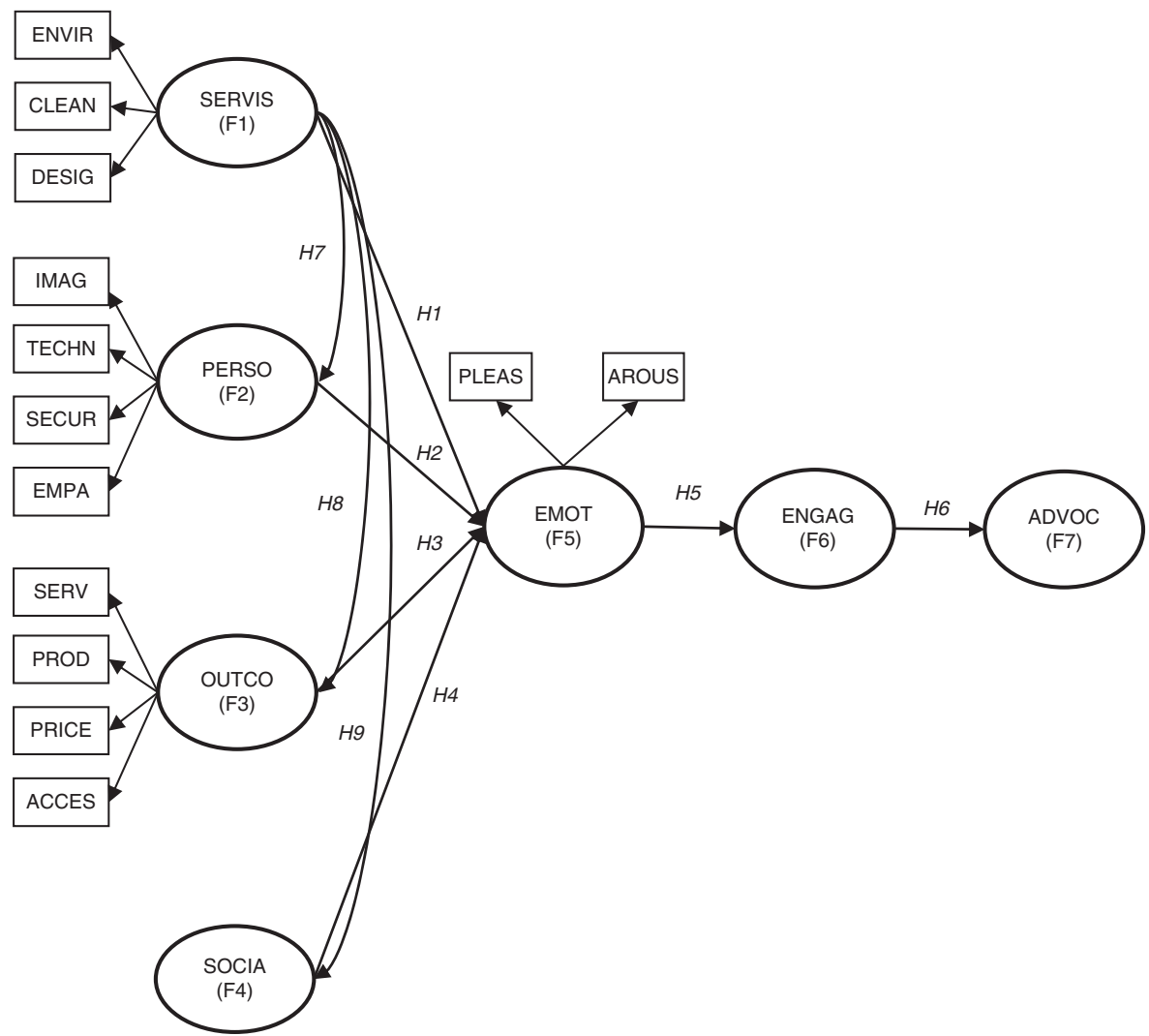

Before starting fieldwork and following the recommendations of Ye et al. (2007) on the design of the questionnaire to counteract "self-generated validity", we pay attention to relevant issues such as the order of the questions, the use of terminology and the language for good comprehension of the interviewees. At the same time, we also conducted a pre-test on bank experts and a group of 25 customers in the last quarter of 2015. This procedure helped to improve the wording of some of the questionnaire items and ensured the appropriate form, layout, difficulty of sequence, length and completion time for the questionnaires. Additionally, care was also taken not to present the constructs in the order set out in our hypotheses (antecedents $\rightarrow$ mediating variables $\rightarrow$ consequences). Finally, the questionnaire was translated from English into Spanish, following the back-translation method of Brislin (1970), widely used in literature, to ensure that the Spanish version was consistent with the original English version.

Then, customers were interviewed by a team of researchers on location during the first quarter of 2016. The bank's manager informed personnel that university researchers would conduct client surveys. The research team conducted the interviews while the customers were waiting to do their paperwork within the bank. The sample of this study saw only the regular customers of the branches. To avoid misinterpretations of the self-completion technique, we used interviews, since this technique associates greater effects caused by common method bias (Podsakoff et al., 2003; Friedrich et al., 2009; Richardson et al., 2009; Williams et al., 2010; Knoll and Gill, 2011; Fuller et al., 2016). The criterion for fieldwork was 
to conduct five interviews with clients in the 225 branches and have a final sample of 1,125 clients. The sample covered 42.45 per cent of all the branches in the studied regions, with a balanced percentage of responses obtained in each of these regions.

The intraclass correlation coefficient (CCI) (Kish, 1962) is used to avoid the possible interviewer effects on results obtained (Hox and Kreft, 1994). The CCI of the results was close to 0.031, which make it recommendable for face-to-face interviews (Groves et al., 2004; Davis et al., 2010).

Table I shows the profile of the resulting sample based on different classification variables. In general, the company maintains that these profiles were affordable with the total portfolio of its customers in each branch.

\subsection{Measurement instruments}

All scales used to measure the different service qualities considered correspond exactly to the theoretical definitions given to them. In all cases, adaptations of scales of other authors, already contrasted in previous studies, were adapted to the bank branch context. The same procedure would happen with the measurement of the constructs of emotions during service, customer engagement and customer advocacy. The Likert scale of 5 points helped to give a valuation to all of the questionnaire items, with 1 meaning "totally disagree" and 5 meaning "totally agree". Table II summarises the sources of the measurement scales used in this study.

\subsection{Preliminary analysis of the data}

First, the variance inflation factors among latent variables form our proposed model which highlighted the absence of multicollinearity signs. The results with values between 1.750

\begin{tabular}{|c|c|c|c|c|c|c|c|}
\hline \multirow{3}{*}{$\begin{array}{l}\text { Gender } \\
\text { Age (Mean: 47) }\end{array}$} & \multicolumn{3}{|c|}{$\begin{array}{c}\text { Men } \\
585(52 \%)\end{array}$} & \multicolumn{3}{|c|}{$\begin{array}{l}\text { Women } \\
540(48 \%)\end{array}$} & \\
\hline & $18-29$ & $30-39$ & $40-49$ & $50-59$ & $60-69$ & 70 or more & \\
\hline & $15 \%$ & $20 \%$ & $21 \%$ & $19 \%$ & $14 \%$ & $11 \%$ & \\
\hline Members at home & $\begin{array}{l}\text { Alone } \\
10 \%\end{array}$ & \multicolumn{2}{|c|}{$\begin{array}{c}2 \text { members } \\
33 \%\end{array}$} & $\begin{array}{c}3 \text { members } \\
24 \%\end{array}$ & $\begin{array}{c}4 \text { members } \\
25 \%\end{array}$ & $\begin{array}{c}5 \text { or more } \\
8 \%\end{array}$ & \\
\hline Incomes & $\begin{array}{c}\text { Below } 1,000 € \\
18 \%\end{array}$ & \multicolumn{2}{|c|}{$\begin{array}{c}1.001-1.500 € \\
28 \%\end{array}$} & $\begin{array}{c}1.501-2.000 € \\
24 \%\end{array}$ & $\begin{array}{c}2.001-2.500 € \\
13 \%\end{array}$ & $\begin{array}{c}\text { Above } 2500 € \\
17 \%\end{array}$ & \\
\hline Occupation & $\begin{array}{c}\text { Employee } \\
55 \%\end{array}$ & \multicolumn{2}{|c|}{$\begin{array}{l}\text { Retired } \\
20 \%\end{array}$} & $\begin{array}{c}\text { Houseworker } \\
10 \%\end{array}$ & $\begin{array}{c}\text { Unemployed } \\
9 \%\end{array}$ & $\begin{array}{c}\text { Students } \\
6 \%\end{array}$ & Table I. \\
\hline Studies & $\begin{array}{c}\text { Primary educ. } \\
19 \%\end{array}$ & \multicolumn{2}{|c|}{$\begin{array}{l}\text { Secondary educ. } \\
19 \%\end{array}$} & \multicolumn{2}{|c|}{$\begin{array}{c}\text { High School } \\
30 \%\end{array}$} & $\begin{array}{l}\text { University educ. } \\
32 \%\end{array}$ & $\begin{array}{r}\text { Sample classification } \\
\text { data }\end{array}$ \\
\hline
\end{tabular}

\begin{tabular}{|c|c|c|}
\hline Variables & References & Items \\
\hline Servicescape quality & $\begin{array}{l}\text { Wang et al. (2003), Reimer and Kuehn (2005), Miles et al. (2012), } \\
\text { Kaura (2013) }\end{array}$ & $17(5+3+7)$ \\
\hline Personnel quality & $\begin{array}{l}\text { Wang et al. (2003), Reimer and Kuehn (2005), Harris and Ezeh (2008), } \\
\text { Kaura (2013) }\end{array}$ & $18(3+7+4+4)$ \\
\hline Outcome quality & Wang et al. (2003), Sánchez et al. (2006), Kaura (2013) & $20(4+3+7+6)$ \\
\hline Social quality & $\begin{array}{l}\text { Mercer (2003), García et al. (2005), Pérez and Rodríguez (2012), } \\
\text { Ha et al. (2014), Liu et al. (2014) }\end{array}$ & 5 \\
\hline $\begin{array}{l}\text { Emotions during } \\
\text { service }\end{array}$ & Mazaheri et al. (2011), Blasco (2014) & $9(6+3)$ \\
\hline Customer engagement & Medlin and Green (2009), Sprott et al. (2009), Blasco (2014) & 4 \\
\hline Customer advocacy & Kemp et al. (2014) & 4 \\
\hline
\end{tabular}

Table II. Scales used
Service quality in a post-crisis context 
IJBM

38,1

186

and 5.488 (considerably lower than the maximum value of 10), suggesting that multicollinearity was not a problem in the study (Kutner et al., 2004; Hair et al., 2010). Second, we performed a $t$-test of independent means on the dimensions of the variables in the model, using the first 45 and last 45 respondents. The absence of non-response bias (Armstrong and Overton, 1977; Collier and Bienstock, 2007) was confirmed as we found no significant differences between these respondents at a level of 0.05 .

Additionally, to contrast a possible "common method variance bias", we used the Harman test for a factor (Harman, 1976), which assumes that if there is a bias from a factorial analysis, it should be expected that one specific factor will accumulate most of the covariates of the independent and dependent variables (Podsakoff and Organ, 1986). In this sense, as recommended by Podsakoff $e t$ al. (2003) a factorial analysis of the 74 indicators resulting from the purification process of the scales, helps to examine the unrotated factorial solution using the component analysis method (Velicer and Jackson, 1990). The results of the factorial analysis show the existence of 13 factors with self-values greater than 1, explaining 77.324 per cent of the variance between the 74 items and the first factor accumulates 38.327 per cent. Thus, due to the identification of various factors and the fact that the first one does not accumulate most of the variance, a substantial part of the variance bias seems not to be present (Podsakoff et al., 2003; Friedrich et al., 2009; MacKenzie and Podsakoff, 2012).

\subsection{Validity and scale reliability}

Confirmatory factor analysis (CFA) was performed using the structural equation model (SEM) to refine the scales with version 6.1 of the EQS multivariate software package. The maximum likelihood approach was adopted to estimate the parameters.

Following Hair et al. (2010), we considered a model development strategy. To improve initial models, we decided to carry out an improvement process through less relevant indicators with elimination based on latent variables' structures assumed for the different constructs. Jöreskog and Sörbom's (1993) recommendations suggest examining the estimation parameters. We eliminated the indicators that did not satisfy the strong convergence condition, that is, those having individuals standardised coefficients lower than 0.6 and an average standardised factor loading of less than 0.7 (Bagozzi and Yi, 1988; Steenkamp and van Trijp, 1991; Hair et al., 2010).

Then, we verified the compliance with the weak convergence condition (Steenkamp and van Trijp, 1991) analysing the significance of the factor regression coefficients between indicators and their latent variables. To do this, we considered the Student $t$-value by imposing the maximum condition $(t>2.58 ; P=0.01)$. Following this process, the elimination of the indicators SERV15 and SERV17 was for presenting loads equal to 0.508 and 0.512 , respectively, from the servicescape quality scale and the indicator OUTC10 for presenting a load equal to 0.583 from outcome quality scale.

Finally, we monitored the evolution of the adjustment measurements of the model with the exclusion of each indicator. We used normed $\chi^{2}$ (Jöreskog, 1969: values between 1 and 4 are correct), the normed fit index NFI (Bentler and Bonett, 1980; Ullman, 2001: value recommendation above 0.90), the non-normed fit index NNFI (Schumacker and Lomax, 1996: value recommendation above 0.90), the incremental fit index IFI and the comparative fit index CFI (Hu and Bentler, 1999: values above 0.90 are acceptable), the root mean square residual RMR (Hu and Bentler, 1999: values below 0.08 are acceptable), and the root mean square of approximation RMSEA (Browne and Cudeck, 1992: values below 0.08 show acceptable setting).

Several verification tests were conducted to identify whether the previous refinement tests, negatively affected reliability scale. As for internal consistency, we tested Cronbach's $\alpha(\alpha>0.7)$, construct composite reliability (CR $>0.7)$, and analysis of variance extracted (AVE > 0.5) (Churchill, 1979; Nunnally, 1978; Fornell and Larcker, 1981) (Table III). 
Servicescape quality $(C R=0.85 ; A V E=0.66)$

Environmental conditions $(\alpha=0.927 ; \mathrm{CR}=0.93 ; \mathrm{AVE}=0.71)$

SERV1: the lighting is appropriate

SERV2: the level of noise is acceptable

SERV3: There is a pleasant ambient temperature

SERV4: the aroma is agreeable

SERV5: in general, it has a warm atmosphere

Conditions of cleanliness $(\alpha=0.931 ; \mathrm{CR}=0.93 ; \mathrm{AVE}=0.81$ )

SERV6: the entrance and waiting area are clean

SERV7: the branch seems to be tidy and organised

SERV8: this branch is generally kept clean

Conditions of design $(\alpha=0.929 ; \mathrm{CR}=0.93 ; \mathrm{AVE}=0.67)$

SERV9: privacy is facilitated by the design

SERV10: the premises are large and spacious

SERV11: the leaflets and communication elements are visually appealing

SERV12: the branch is attractively decorated

SERV13: the building's architecture is attractive

SERV14: the colours are attractive

SERV15: it is easily accessible

SERV16: it has modern equipment

SERV17: the furniture is attractive and comfortable

Personnel quality $(C R=0.92 ; A V E=0.74)$

Conditions of image $(\alpha=0.944 ; \mathrm{CR}=0.94 ; \mathrm{AVE}=0.84)$

PERS1: the employees look clean and tidy

PERS2: the employees have a good appearance

PERS3: the employees dress smartly

Technical conditions $(\alpha=0.959 ; \mathrm{CR}=0.96 ; \mathrm{AVE}=0.77)$

PERS4: the employees know how to work

PERS5: the employees are well trained

PERS6: the employees provide valuable and useful information

PERS7: they are familiar with the services the bank offers

PERS8: they provide a fast service

PERS9: they are able to solve my problems

PERS10: they attend to me without making mistakes

Conditions of confidence $(\alpha=0.944 ; \mathrm{CR}=0.94 ; \mathrm{AVE}=0.81)$

PERS11: the employees' behaviour conveys trust

PERS12: the transactions undertaken with the staff inspire me with confidence

PERS13: the employees are always polite

PERS14: they have the necessary knowledge to answer my questions

Conditions of empathy $(\alpha=0.911 ; \mathrm{CR}=0.91 ; \mathrm{AVE}=0.73)$

PERS15: opening times are convenient for all the bank's customers

PERS16: they understand the customer's specific needs

PERS17: they have the customer's best interests at heart

PERS18: they give personal attention to customers

Outcome quality $(C R=0.81 ; A V E=0.57)$

Service conditions $(\alpha=0.892 ; \mathrm{CR}=0.91 ; \mathrm{AVE}=0.71)$

OUTC1: on the whole, the service I have received is fitting

OUTC2: compared with other banks the level of quality here is acceptable

OUTC3: I received the service I expected

OUTC4: I am happy with the outcome I obtained

Product conditions $(\alpha=0.933 ; \mathrm{CR}=0.94 ; \mathrm{AVE}=0.84)$
Factor loads

t-value

Service quality in a post-crisis

context

\begin{tabular}{lr}
0.807 & $17.620^{*}$ \\
0.766 & Fixed \\
0.865 & $21.685^{*}$ \\
0.833 & $21.345^{*}$ \\
0.858 & $20.368^{*}$ \\
0.895 & $22.545^{*}$ \\
0.741 & $17.771^{*}$ \\
0.840 & Fixed \\
0.919 & $30.556^{*}$ \\
0.938 & $34.124^{*}$ \\
0.880 & $18.774^{*}$ \\
0.711 & Fixed \\
0.715 & $23.881^{*}$ \\
0.733 & $20.461^{*}$ \\
0.892 & $22.615^{* * *}$ \\
0.863 & $21.826^{*}$ \\
0.900 & $20.987^{*}$ \\
\multicolumn{2}{c}{ Delated } \\
0.891 & $22.643^{*}$ \\
\multicolumn{2}{c}{ Delated }
\end{tabular}

0.708

17.112*

0.949

0.931

0.874

0.916

0.882

0.889

0.908

0.862

0.831

0.896

0.884

0.916

0.904

0.924

0.870

0.895

0.879

0.679

0.903

0.910

0.602

Fixed

41.698*

$38.467^{*}$

$23.632^{*}$

Fixed

37.266*

$32.125^{*}$

$27.477^{*}$

29.951*

29.864*

$32.897^{*}$

26.430*

Fixed

41.880*

28.246*

$32.562 *$

19.737*

Fixed

20.479*

$20.452 *$

18.808*

0.911

0.874

24.674*

Fixed

$0.890 \quad 35.890 *$

$0.664 \quad 20.190 *$

$0.918 \quad 39.902 *$

$0.735 \quad 22.756^{*}$
Table III.

Summary of the results after factor, reliability and validity analyses 
OUTC5: the employees have a thorough knowledge of their job

OUTC13: there are no hidden costs in the services offered

OUTC14: information is provided about any modifications to charges

Access conditions $(\alpha=0.879 ; \mathrm{CR}=0.89 ; \mathrm{AVE}=0.57)$

OUTC15: in general I do not have to wait long in line

OUTC16: I usually get an agile and quick service

OUTC18: the total effort I make to carry out the management in the

Social quality $(\alpha=0.934 ; C R=0.94 ; A V E=0.75)$

SOCI1: they are honest with their customers

SOCI2: they meet their contractual obligations with the customer

SOCI3: they are aware of social causes

SOCI4: they are committed to ethical principles

SOCI5: they are committed to improving welfare in the neighbourhood/city where

Emotions during the service $(C R=0.86 ; A V E=0.75)$

Pleasure $(\alpha=0.950 ; \mathrm{CR}=0.95 ; \mathrm{AVE}=0.77)$

EMO1: angry/glad

EMO2: sad/cheerful

EMO3: unhappy/happy

EMO4: dissatisfied/satisfied

EMO5: disappointed/excited

EMO6: annoyed/pleased

EMO7: indifferent/unexpected

EMO8: not amazed at all/very amazed

Engagement $(\alpha=0.936 ; C R=0.94 ; A V E=0.80)$

ENGA1: I feel valued in my interactions with the branch

ENGA2: I feel as though I have a personal relationship with my branch

Advocacy $(\alpha=0.937 ; C R=0.94 ; A V E=0.80)$

ADVO1: I recommend my bank to my friends and family

ADVO2: when the occasion arises I explain positive aspects of my bank

Fit of the model: $\chi^{2} / \mathrm{df}=8,225.213 / 2,593=3.172 ; \mathrm{NFI}=0.863 ; \mathrm{NNFI}=0.908 ; \mathrm{IFI}=0.912 ; \mathrm{CFI}=0.912$; $\mathrm{SRMR}=0.051 ; \mathrm{RMSEA}=0.045$ 
Next, we analysed convergent and discriminant validity. To verify the former, we returned to our initial CFA and observed the estimated value and significance of the correlations between dimensions of the scales (Monferrer et al., 2016). The relatively high and significant correlations confirm the convergent validity. Table IV indicates constructs discriminant validity, confirmed through AVE (Fornell and Larcker, 1981). When the square root of the AVE between each pair of factors is higher than the estimated correlation between those factors, as occurs here, discriminant validity is confirmed.

\section{Analysis and findings}

First of all, it is advisable to refer to the necessity for us to adapt our database for use in the programme EQS6.1. Thus, the reduction of multidimensional scales related to service quality and emotional factors during the service helps to calculate the weighted mean of the indicators that compose it, resulting from the analysis of validity and reliability (MacKenzie and Lutz, 1989; Hair et al., 2010). Figure 2 shows the step diagram of the resulting relationship model after its specification and identification.

The next step is to contrast hypotheses with the EQS multivariate software package 6.1 version of SEM. Focusing on each hypothesis proposed in the model and the results

\begin{tabular}{llllllll}
\hline & 1 & 2 & 3 & 4 & 5 & 6 & 7 \\
\hline 1. Servicescape quality & 0.81 & & & & & & \\
2. Personnel quality & $0.74^{*}$ & 0.86 & & & & & \\
3. Outcome quality & $0.69^{*}$ & $0.71^{*}$ & 0.76 & & & & \\
4. Social quality & $0.19^{*}$ & $0.33^{*}$ & $0.38^{*}$ & 0.87 & & & \\
5. Emotions during the service & $0.39^{*}$ & $0.49^{*}$ & $0.60^{*}$ & $0.37^{*}$ & 0.87 & & \\
6. Engagement & $0.49^{*}$ & $0.64^{*}$ & $0.64^{*}$ & $0.36^{*}$ & $0.53^{*}$ & 0.90 & \\
7. Advocacy & $0.26^{*}$ & $0.39^{*}$ & $0.48^{*}$ & $0.40^{*}$ & $0.51^{*}$ & $0.50^{*}$ & 0.89
\end{tabular}

Notes: Below the diagonal: correlation estimated between the factors. Diagonal: square root of AVE. $* p<0.01$
Service quality in a post-crisis context

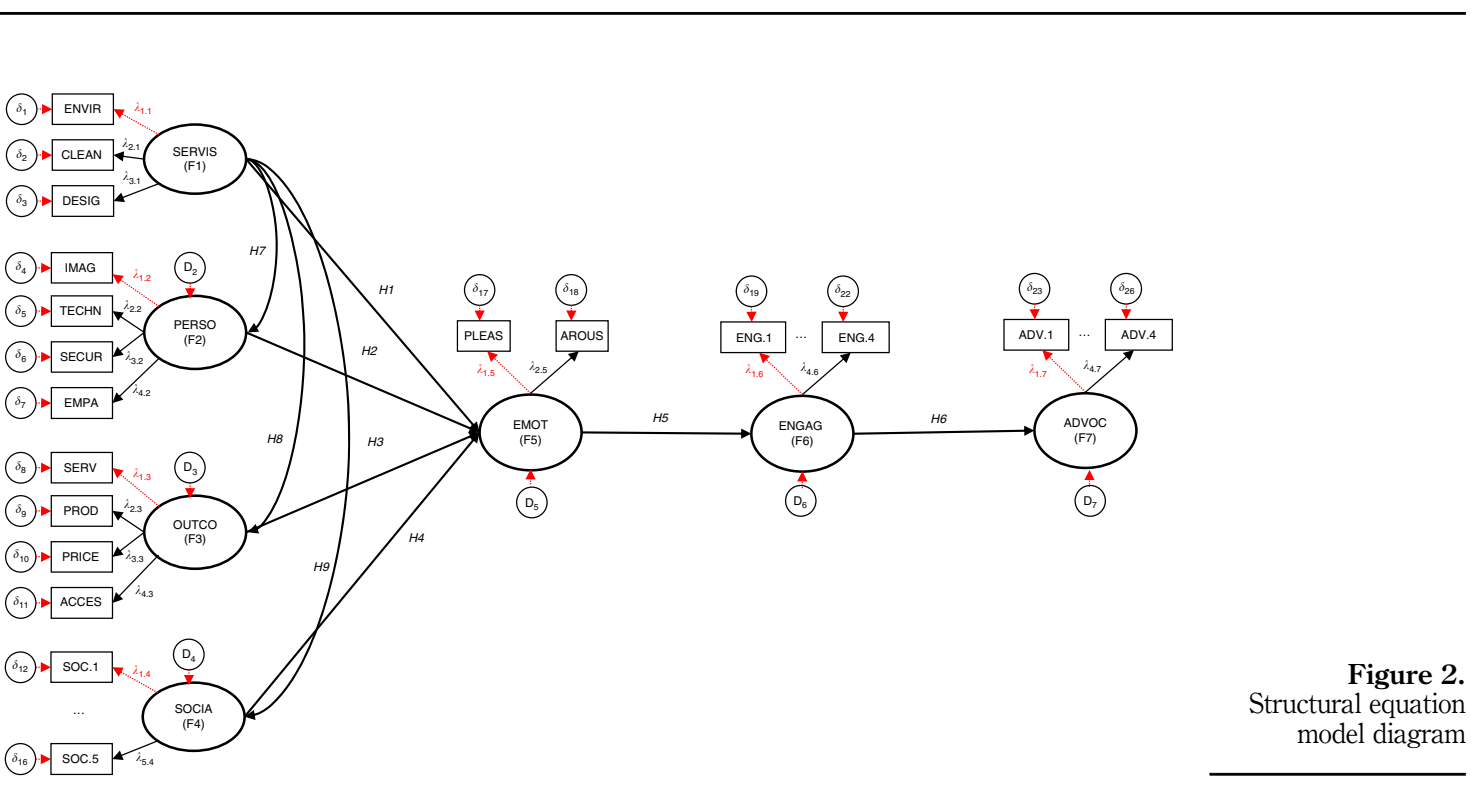


IJBM

38,1

190

obtained after its estimations is observed, in a global way, that service quality is a determinant of emotions during service in branches (Table V). In particular, we have found two primary service quality factors in the generation of positive emotions, which are personnel quality ( $H 2: \lambda=0.347 ; t=2.142)$ and outcome quality $(H 3: \lambda=0.350 ; t=3.272$ ). We add the secondary influence of social quality $(H 4: \lambda=0.195 ; t=5.776)$ to these effects. However, servicescape quality, linked to tangibility, is not significant in the generation of emotions in negative relational contexts, such as the analysed post-crisis period ( $\mathrm{H1}$ : $\lambda=0.095 ; t=0.370$ ).

Additionally, emotions experienced by customers during service at branches are decisive for the strengthening of their interpersonal relationship with the branch, both directly from the reinforcement of the engagement ( $H 5: \lambda=0.795 ; t=17.240)$, as well as indirectly from customer engagement in relation to customer advocacy $(H 6: \lambda=0.522 ; t=15.629)$.

On the other hand, according to the interrelation of service quality dimensions, the results demonstrate the existence of a positive and significant influence between servicescape quality (tangible nature) and intangible dimensions such as personnel quality (H7: $\lambda=0.937 ; t=18.352)$, outcome quality $(H 8: \lambda=0.873 ; t=20.117)$ and social quality (H9: $\lambda=0.387 ; t=10.370)$.

Moreover, the revision of the total effects derived from the proposed relationship model shows the positive influence between the service quality variables on the different relational factors (Bentler, 2006). In particular, Table VI shows that although the direct causal effect of servicescape quality was not significant in the hypothesis testing, the influence of this variable on the relational factors studied is relevant thanks to the indirect effect exerted on the other service quality variables. Therefore, they confirm the relevance of the interrelation between the service quality variables of a more tangible and intangible nature.

\section{Conclusions and implications}

The aim of the study was to analyse service quality dimensions impact on emotional and relational customer behaviours paying attention to customer non-transactional behaviours (customer engagement and advocacy) in a post-crisis context. Adopting a micro approach, the study focussed on the Spanish banking sector under the analysis of a financial institution at branch level. This situation allowed us to identify relational marketing activities at a micro level.

This sector suffered serious consequences in customer relations in a deeper and more direct way due to the last economic crisis in Spain. For this reason, in this moment of recovery of the competitive and relational capacity by the banks (Kaura et al., 2015; Sayani, 2015), the identification of the most determinant factors in the maintenance of positive

\begin{tabular}{llccl}
\hline Hypotheses & Path & Parameter & $t$-value & Result \\
\hline$H 1$ & Servicescape quality $\rightarrow$ Emotions during service & 0.095 & 0.370 & Not supported \\
$H 2$ & Personnel quality $\rightarrow$ Emotions during service & 0.347 & $2.142^{*}$ & Supported \\
$H 3$ & Outcome quality $\rightarrow$ Emotions during service & 0.350 & $3.272^{* *}$ & Supported \\
$H 4$ & Social quality $\rightarrow$ Emotions during service & 0.195 & $5.776^{* * *}$ & Supported \\
$H 5$ & Emotions during service $\rightarrow$ Customer engagement & 0.795 & $17.240^{* * *}$ & Supported \\
$H 6$ & Customer engagement $\rightarrow$ Customer advocacy & 0.522 & $15.629^{* * *}$ & Supported \\
$H 7$ & Servicescape quality $\rightarrow$ Personnel quality & 0.937 & $18.352^{* * *}$ & Supported \\
$H 8$ & Servicescape quality $\rightarrow$ Outcome quality & 0.873 & $20.117^{* * *}$ & Supported \\
$H 9$ & Servicescape quality $\rightarrow$ Social quality & 0.387 & $10.370^{* * *}$ & Supported
\end{tabular}

Table V.

Summary results of the structural model
Fit of the model: $\chi^{2} / \mathrm{df}=8,225.213 / 2,593=3.172$; NFI $=0.863 ; \mathrm{NNFI}=0.908 ; \mathrm{IFI}=0.912 ; \mathrm{CFI}=0.912$; $\mathrm{SRMR}=0.051 ; \mathrm{RMSEA}=0.045$

Notes: $* p<0.05 ; * * p<0.01 ; * * * p<0.001$ 


\begin{tabular}{|c|c|c|c|c|c|}
\hline \multirow[b]{2}{*}{ Path } & \multicolumn{2}{|c|}{ Total effects } & \multicolumn{2}{|c|}{ Indirect effects } & \multirow{2}{*}{$\begin{array}{l}\text { Service quality } \\
\text { in a post-crisis }\end{array}$} \\
\hline & Parameter & $t$-value & Parameter & $t$-value & \\
\hline Servicescape quality $\rightarrow$ Personnel quality & 0.937 & $18.352^{* * * *}$ & & & \\
\hline Servicescape quality $\rightarrow$ Outcome quality & 0.873 & $20.117 * * *$ & & & \\
\hline Servicescape quality $\rightarrow$ Social quality & 0.387 & $10.370 * * *$ & & & \\
\hline Servicescape quality $\rightarrow$ Emotions during service & 0.800 & $13.738 * * *$ & 0.705 & $2.935 * *$ & \\
\hline Personnel quality $\rightarrow$ Emotions during service & 0.347 & $2.142^{*}$ & & & 191 \\
\hline Outcome quality $\rightarrow$ Emotions during service & 0.35 & $3.272 * *$ & & & \\
\hline Social quality $\rightarrow$ Emotions during service & 0.195 & $5.776^{* * * *}$ & & & \\
\hline Emotions during service $\rightarrow$ Customer engagement & 0.795 & $17.240 * * *$ & & & \\
\hline Servicescape quality $\rightarrow$ Customer engagement & 0.636 & $14.829 * * *$ & 0.636 & $14.829 * * *$ & \\
\hline Personnel quality $\rightarrow$ Customer engagement & 0.275 & $2.145^{*}$ & 0.275 & $2.145^{*}$ & \\
\hline Outcome quality $\rightarrow$ Customer engagement & 0.278 & $3.281^{* *}$ & 0.278 & $3.281 * *$ & \\
\hline Social quality $\rightarrow$ Customer engagement & 0.155 & $5.850 * * *$ & 0.155 & $5.850 * * * *$ & \\
\hline Emotions during service $\rightarrow$ Customer advocacy & 0.415 & $12.172 * * *$ & 0.415 & $12.172^{* * * *}$ & \\
\hline Customer engagement $\rightarrow$ Customer advocacy & 0.522 & $15.629 * * *$ & & & \\
\hline Servicescape quality $\rightarrow$ Customer advocacy & 0.332 & $11.181^{* * *}$ & 0.332 & $11.181^{* * *}$ & \\
\hline Personnel quality $\rightarrow$ Customer advocacy & 0.144 & $2.133^{*}$ & 0.144 & $2.133^{*}$ & 1at \\
\hline Outcome quality $\rightarrow$ Customer advocacy & 0.145 & $3.222 * *$ & 0.145 & $3.222^{* * *}$ & \\
\hline Social quality $\rightarrow$ Customer advocacy & 0.081 & $5.538 * * *$ & 0.081 & $5.538 * * *$ & \\
\hline Notes: $* p<0.05 ; * * p<0.01 ; * * * p<0.001$ & & & & & \\
\hline
\end{tabular}

relations with the clients has aroused an extraordinary interest both in the scientific community as also in the managerial field (Strandberg et al., 2012; Ha et al., 2014; Marinkovic and Obradovic, 2015; Sayani, 2015; Zameer et al., 2015; Monferrer et al., 2016; Pansari and Kumar, 2017; Estrada et al., 2018; Moliner et al., 2018).

\subsection{Theoretical implications}

First of all, our results fit with the life-course paradigm which postulates that the thoughts and actions of the consumers should vary according to the circumstances of life that these aforementioned experience (Bennett and Kottasz, 2012; Monferrer et al., 2016). These circumstances include factors of the physical or social environment experienced in relatively long periods of time, such as periods of prosperity or economic crisis (Moliner et al., 2019). The global crisis definitely affected consumer attitudes and behaviours. In fact, Bennett and Kottasz (2012) already predicted that public attitudes towards financial institutions after the crisis would be subject to substantial change. The present work provides clarity around the concrete ways of this change.

Deepening the particular direct effects of each of the four dimensions considered on the service quality, we realise that, in a post-crisis context like the present one, the three variables of a more intangible nature (personnel, outcome and social qualities) are central dimensions in the determination of the positive emotions generated by the client during service in the offices. Two of them, personnel quality and outcome quality, would act as first-order dimensions (with substantially higher factorial loads) and social quality would have a second-order direct relevance ahead of servicescape quality which, associated with aspects of a more tangible mention, would not have direct effects in this regard.

Therefore, we see that personnel and outcome qualities (directly associated with the service itself which was provided to the customer) are the only ones out of the three qualities of the service traditionally studied in the literature which have emotional and relational effects on the client. This fact allows us to confirm that, in negative interactive contexts, clients tend to present a much more result-oriented attitude in the evaluation of the service provided to them (Monferrer et al., 2016). In effect, the client focuses on the 
IJBM

38,1

efficiency with which the financial institution provides its services, modifying the role played by the servicescape quality, related to elements that complement the main service provided by the branch.

On the other hand, we contrast the direct effect of social quality on the client's emotions, which allows us to conclude that the client expressly rewards those companies linked to socially directed actions, not only to the client's own benefit but also to that of society as a whole. This result implies relevant implications from the academic and business view (Pérez and Rodríguez, 2012; Ha et al., 2014). In relation to that effect, it confirms the need to consider social quality as an additional element associated with service quality, traditionally defined from the other three qualities considered in this paper, whose study until now has been totally embryonic in the literature, even more so when we refer to the services sector (Pérez and Rodríguez, 2012; Liu et al., 2014). For its part, from the managerial point of view, this result represents empirical support to the social strategies and actions carried out in recent years by the banking sector to the point of becoming one of the most proactive industries in this field (McDonald and Rundle, 2008; Pérez and Rodríguez, 2012; Liu et al., 2014).

In general, our study represents an important contribution to the specific involvement of each dimension under a joint and holistic consideration of them. In this way, it responds to the limitations recently highlighted in the literature regarding the possible bias in the results achieved in studies focussed in a particular way and isolated in some of the qualities referred to (García et al., 2005; Ha et al., 2014; Monferrer et al., 2016). These studies would present an incomplete view of the general evaluation of the service made by the client, making the simultaneous consideration of the different elements of quality that intervene in the provision of the customer service necessary, as is the case.

Additionally, our work deepens the antecedent role of these dimensions, completing it with the analysis of the possible existence of interrelationships between them. Specifically and based on the different tangible/intangible nature of the service quality dimensions, we see that the role of servicescape quality is also relevant because through its indirect influence it would act as positive reinforcement on the rest of the dimensions. This consideration concurs with the assumptions maintained by Monferrer et al. (2016) that advocate differentiating two types of service qualities: those that relate to the "what" (is offered) and those associated with the "how" (it is offered). In this sense, banks should not sacrifice servicescape quality in order to maximise their relational capacity. Although the past crisis has strengthened the fact that we are in a period in which customers focus on the most essential aspects of service quality. This is not considered as a stimulus to reduce the quality of the facilities and environment in which the service is provided.

On the other hand, our work reflects the growing importance of new constructs associated with the relationship quality between clients and branches under a non-transactional emotional approach, which allows us to have a complementary vision of classic studies focussed on variables such as satisfaction, confidence and loyalty (Kumar et al., 2010; Monferrer et al., 2016). Also, this study drew on the recent framework of customer engagement proposed by Pansari and Kumar (2017), according to which customer engagement (the variable that has not been widely used in the analysis of bank customer behaviour) is a mediator variable between emotions and non-action behaviours such as customer advocacy. In this sense, positive emotions during service in bank branches cause two consequences. First and directly, this study demonstrates that customer engagement establishes a close emotional bond between the bank and customers being central to transforming the customer's emotional experience with the bank branch in certain post-purchase behaviours (Brodie and Hollebeek, 2011).

Second and indirectly, customer advocacy helps to promote the bank to customers' social circles such as family and friends and to speak positively about it on social media. 
From a theoretical approach some literature assumes that these constructs would be closely related, but to date, few studies had confirmed it (Kumar, 2013; Moliner et al., 2019). Therefore, generating positive emotions and non-transactional behaviours means customers are more profitable to the bank by becoming bank advocates (Ou and Verhoef, 2017; Moliner et al., 2019).

\subsection{Managerial implications}

Key moments in branch offices, as our results demonstrate, are crucial aspects of the retail bank strategy. In this sense, the different dimensions of service quality play a determining role in generating customer emotions that influence customer engagement and customer advocacy.

Banks should try to create strong emotional ties with their customers and, to do so, they must design scenarios and procedures in their offices that generate positive emotional atmospheres for their customers. The marketing managers of the institutes must make efforts not only to establish stable long-term relationships with clients (relational marketing) but also to establish intense emotional links with them by offering experiences of pleasant service (experiential marketing) since these will be determinants of the first.

In this sense, international Spanish banks such as Banco Santander, BBVA and Caixa Bank seem to have taken this first step by implementing a new strategy to establish and strengthen relations with their customers through the provision of face-to-face service based on the generation of positive experiences and emotions. In particular, we observed a process of radical renovation of the traditional concept of the branch that intends to become a place to attend and advise customers with a view to becoming a central focus to encourage and facilitate a more personal and durable service in the future. This transformation would include longer opening hours, a more accessible, agile and digital design, and the intent on attracting customer attention from the outset. The importance of the social component, in line with our results, will be crucial. Thus, the facilities would have equipment such as hearing aids for people with hearing problems, accessible ATMs and information in Braille. The offices would also be more efficient and sustainable, without architectural barriers and with intelligent heating, air conditioning and lighting systems. The furniture would be more ergonomic and used to create open spaces providing conversation areas, meeting rooms and workspaces that encourage better communication between the bank's personnel and their customers.

In this sense, in the face of the vigorous exploitation of online media, banking in the future should try to ensure that the multiple channels of access to the banking service facilities are offered to their clients and are considered as complementary rather than exclusionary. To combine the current online and offline functions, the role of branches is to make modifications through actions such as those described above, which will give them the ability to provide added value to the customer. The purpose of this strategy would be to integrate traditional branches with access to different channels that new technologies have made available to customers. In this way, the different channels would complement each other and together would increase the value offered to the customer.

This new strategy based on an experiential and emotional commitment, in line with the results obtained in this study, will allow the banks to be even closer and more connected with their clients and to strengthen their relationship with them using the excellence of their service quality as the starting point.

\section{Limitations and future research}

The research findings have several limitations such as cross-sectional data collection, customer sample of a specific financial institute and the average opinion of five customers per branch. The number of customers per branch should be increased for more precise results.
Service quality in a post-crisis context 
Proposals for future research include extending the study sample to other sectors and banks to support our conclusions. Non-transactional behaviours in the online context would be a potential line of study. Nowadays, a growing percentage of the population carry out all their transaction online, leaving face-to-face banking service to solve other kinds of problems. This scenario raises new challenges for experiential marketing.

\section{References}

Amin, M. and Isa, Z. (2008), "An examination of the relationship between service quality perception and customer satisfaction: a SEM approach towards Malaysian Islamic banking”, International Journal of Islamic and Middle Eastern Finance and Management, Vol. 1 No. 3, pp. 191-209.

Amin, M., Yahya, Z., Ismayatim, W.F.A., Nasharuddin, S.Z. and Kassim, E. (2013), "Service quality dimension and customer satisfaction: an empirical study in the Malaysian hotel industry", Services Marketing Quarterly, Vol. 11 No. 3, pp. 217-228.

Aranda, R.A.C. and Sotomayor, M.E.M. (2016), "Social responsibility in the Spanish financial system", Social Responsibility Journal, Vol. 12 No. 1, pp. 103-116.

Armstrong, J.S. and Overton, T.S. (1977), "Estimating nonresponse bias in mail surveys", Journal of Marketing Research, Vol. 14 No. 3, pp. 396-402.

Bagozzi, R.P. and Yi, Y. (1988), "On the evaluation of structural equation models", Journal of the Academy of Marketing Science, Vol. 16 No. 1, pp. 74-94.

Bagozzi, R.P., Belanche, D., Casaló, L.V. and Flavián, C. (2016), "The role of anticipated emotions in purchase intentions", Psychology and Marketing, Vol. 33 No. 2, pp. 629-645.

Batson, C.D. (1991), The Altruism Question: Toward a Social-psychological Answer: The Altruism Question: Toward a Social-psychological Answer, Lawrence Erlbaum Associates, Hillside, NJ.

Bennett, R. and Kottasz, R. (2012), "Public attitudes towards the UK banking industry following the global financial crisis”, International Journal of Bank Marketing, Vol. 30 No. 2, pp. 128-147.

Bentler, P.M. (2006), EQS 6 Structural Equations Program Manual, BMDP Statistic Software, Los Angeles, CA.

Bentler, P.M. and Bonett, D.G. (1980), "Significance tests and goodness of fit in the analysis of covariance structures", Psychological Bulletin, Vol. 88 No. 3, pp. 588-606.

Bigné, A.E. and Andreu Simó, L. (2005), "Effects of environmental variables and attribution of emotions in shopping centers: an application in buying perfume and cosmetics", Spanish Journal of Marketing Research, Vol. 10 No. 1, pp. 45-68.

Bitner, M.J. (1992), "Servicescapes: the impact of physical surroundings on customers and employees", Journal of Marketing, Vol. 56 No. 2, pp. 57-71.

Booms, B.H. and Bitner, M.J. (1981), "Marketing strategies and organization structures for service firms", Marketing of Services, Vol. 25 No. 3, pp. 47-51.

Brady, M.K. and Cronin, J.J. (2001), "Some new thoughts on conceptualizing perceived service quality: a hierarchical approach", Journal of Marketing, Vol. 65 No. 3, pp. 34-49.

Brislin, R.W. (1970), "Back-translation for cross-cultural research”, Journal of Cross-Cultural Psychology, Vol. 1 No. 3, pp. 185-216.

Brodie, R.J. and Hollebeek, L.D. (2011), "Advancing and consolidating knowledge about customer engagement”, Journal of Service Research, Vol. 14 No. 3, pp. 283-284.

Cambra, F.J., Melero Polo, I. and Sese, F.J. (2016), "Can complaint-handling efforts promote customer engagement?”, Service Business, Vol. 10 No. 4, pp. 847-866.

Carroll, A.B. (1991), "The pyramid of corporate social responsibility: toward the moral management of organizational stakeholders", Business Horizons, Vol. 34 No. 4, pp. 39-48.

Chahal, H. and Dutta, K. (2015), "Measurement and impact of customer experience in banking sector", Decision, Vol. 42 No. 1, pp. 57-70. 
Chelminski, P. and Coulter, R.A. (2011), "An examination of consumer advocacy and complaining behavior in the context of service failure”, Journal of Services Marketing, Vol. 25 No. 5, pp. 361-370.

Chou, T.J., Chang, E.C., Zheng, Y. and Tang, X. (2016), "What makes consumers believe: the impacts of priming and sequential service experiences on consumer emotions and willingness to pay", Journal of Services Marketing, Vol. 30 No. 1, pp. 119-127.

Choudhury, K. (2014), "Service quality and word of mouth: a study of the banking sector", Marketing Intelligence and Planning, Vol. 32 No. 7, pp. 612-627.

Churchill, G.A. (1979), “A paradigm for developing better measures of marketing constructs”, Journal of Marketing Research, Vol. 16 No. 1, pp. 64-73.

Collier, J.E. and Bienstock, C.C. (2007), “An analysis of how nonresponse error is assessed in academic marketing research”, Marketing Theory, Vol. 7 No. 2, pp. 163-183.

Dabholkar, P.A., Thorpe, D.I. and Rentz, J.O. (1996), “A measure of service quality for retail stores: scale development and validation”, Journal of the Academy of Marketing Science, Vol. 24 No. 1, pp. 3-16.

Davis, R.E., Couper, M.P., Janz, N.K., Caldwell, C.H. and Resnicow, K. (2010), "Interviewer effects in public health surveys", Health Education Research, Vol. 25 No. 1, pp. 14-26.

Decker, O.S. (2004), "Corporate social responsibility and structural change in financial services", Managerial Auditing Journal, Vol. 19 No. 6, pp. 712-728.

Estrada, E.M., Monferrer, T.D. and Moliner, T.M.A. (2018), "Improving relationship quality during the crisis | 提高危机期间的关系质量”, Service Industries Journal, pp. 1-22, available at: https:// doi.org/10.1080/02642069.2018.1441829

Fatima, J.K. and Razzaque, M.A. (2014), "Service quality and satisfaction in the banking sector", International Journal of Quality \& Reliability Management, Vol. 31 No. 4, pp. 367-379.

Fornell, C. and Larcker, D.F. (1981), "Structural equation models with unobservable variables and measurement error: algebra and statistics”, Journal of Marketing Research, Vol. 18 No. 1, pp. 39-50.

Friedrich, T.L., Byrne, C.L. and Mumford, M.D. (2009), "Methodological and theoretical considerations in survey research”, Leadership Quarterly, Vol. 20 No. 2, pp. 57-60.

Fuller, C., Simmering, M.J., Atinc, G. and Babin, B.J. (2016), "Common methods variance detection in business research”, Journal of Business Research, Vol. 69 No. 8, pp. 3192-3198.

Fullerton, G. (2011), “Creating advocates: the roles of satisfaction, trust and commitment”, Journal of Retailing and Consumer Services, Vol. 18 No. 1, pp. 92-100.

García, D.L.S., Crespo, A.H. and Del Bosque, I.R. (2005), "Influence of corporate social responsibility on loyalty and valuation of services", Journal of Business Ethics, Vol. 61 No. 4, pp. 369-385.

García, G.J.M., Chamorro Mera, A. and Barroso-Méndez, M.J. (2016), “Financial firms’ social activities and how they influence their customers' preference structure”, Social Responsibility Journal, Vol. 12 No. 1, pp. 69-84.

Goplani, R.M. (2013), "Empirical investigation of service quality in retail banking: comparison of state bank of India and ICICI bank, Ahmedabad", International Journal of Research in Commerce \& Management, Vol. 4 No. 3, pp. 93-96.

Grönroos, C. (1984), “A service quality model and its marketing implications”, European Journal of Marketing, Vol. 18 No. 4, pp. 36-44.

Groves, R.M., Fowler, F.J. Jr, Couper, M.P., Lepkowski, J.M., Singer, E. and Tourangeau, R. (2004), Survey Methodology, John Wiley, New York, NY.

Ha, H.Y., Akamavi, R.K., Kitchen, P.J. and Janda, S. (2014), "Exploring key antecedents of purchase intentions within different services”, Journal of Services Marketing, Vol. 28 No. 7, pp. 595-606.

Hair, J.F., Black, W.C., Babin, B.J. and Anderson, R.E. (2010), Multivariate Data Analysis, 7th ed., Pearson, New York, NY.

Hansen, T. (2014), "The role of trust in financial customer-seller relationships before and after the financial crisis", Journal of Consumer Behaviour, Vol. 13 No. 6, pp. 442-452.
Service quality in a post-crisis context 
IJBM 38,1

Harman, H.H. (1976), Modern Factor Analysis, 3rd ed., The University of Chicago Press, Chigaco, IL.

Harris, L.C. and Ezeh, C. (2008), "Servicescape and loyalty intentions: an empirical investigation", European Journal of Marketing, Vol. 42 Nos 3/4, pp. 390-422.

Hooper, D., Coughlan, J. and Mullen, M.R. (2013), "The servicescape as an antecedent to service quality and behavioral intentions", Journal of Services Marketing, Vol. 27 No. 4, pp. 271-280.

Hox, J.J. and Kreft, I.G.G. (1994), "Multilevel analysis methods", Sociological Methods \& Research, Vol. 22 No. 3, pp. 300-318.

Hu, L.T. and Bentler, P.M. (1999), "Cutoff criteria for fit indexes in covariance structure analysis: conventional criteria versus new alternatives", Structural Equation Modeling, Vol. 6 No. 1, pp. 1-55.

Johnson, D.S. and Peterson, M. (2014), “Consumer financial anxiety: US regional financial service firms' trust building response to the financial crisis", International Journal of Bank Marketing, Vol. 32 No. 6, pp. 515-533.

Jöreskog, K.G. (1969), "A general approach to confirmatory maximum likelihood factor analysis", Psychometrika, Vol. 34 No. 2, pp. 183-202.

Jöreskog, K.G. and Sörbom, D. (1993), LISREL 8: Structural Equation Modeling with the SIMPLIS Command Language, Scientific Software International and Lawrence Erlbaum Associates, Inc., Chicago, IL and Hillsdale, NJ.

Juran, J.M. and Godfrey, A.B. (1999), Juran's Quality Handbook, McGrawHill, New York, NY.

Kassim, N. and Souiden, N. (2007), "Customer retention measurement in the UAE banking sector", Journal of Financial Services Marketing, Vol. 11 No. 3, pp. 217-228.

Kaura, V. (2013), "Antecedents of customer satisfaction: a study of Indian public and private sector banks”, International Journal of Bank Marketing, Vol. 31 No. 3, pp. 167-186.

Kaura, V., Durga Prasad, C.S. and Sharma, S. (2015), "Service quality, service convenience, price and fairness, customer loyalty, and the mediating role of customer satisfaction", International Journal of Bank Marketing, Vol. 33 No. 4, pp. 62-77.

Kish, L. (1962), "Studies of interviewer variance for attitudinal variables", Journal of the American Statistical Association, Vol. 57 No. 297, pp. 92-115.

Knoll, D.L. and Gill, H. (2011), “Antecedents of trust in supervisors, subordinates, and peers”, Journal of Managerial Psychology, Vol. 26 No. 4, pp. 313-330.

Kotler, P. and Lee, N. (2005), Corporate Social Responsibility: Doing the Most Good for your Company and your Cause (Source: Academy of Management Perspectives), John Wiley \& Sons Inc., Hoboken, NJ.

Kumar, R.S. (2013), “Consequences of customer advocacy”, Journal of Strategic Marketing, Vol. 21 No. 3, pp. 260-276.

Kumar, R.S., Eshghi, A. and Quazi, A. (2014), “Consumer advocacy's impact on satisfaction and loyalty", Journal of Services Research, Vol. 14 No. 1, pp. 161-182.

Kumar, V., Aksoy, L., Donkers, B., Venkatesan, R., Wiesel, T. and Tillmanns, S. (2010), "Undervalued or overvalued customers: capturing total customer engagement value”, Journal of Service Research, Vol. 13 No. 3, pp. 297-310.

Kutner, M.H., Nachtsheim, C.J., Neter, J. and Li, W. (2004), Applied Statistical Linear Models, McGraw-Hill, New York, NY.

Laros, F.J.M. and Steenkamp, J.B.E.M. (2005), "Emotions in consumer behavior: a hierarchical approach", Journal of Business Research, Vol. 5 No. 10, pp. 1437-1445.

Liu, M.T., Wong, I.A., Shi, G., Chu, R. and Brock, J.L. (2014), "The impact of corporate social responsibility (CSR) performance and perceived brand quality on customer-based brand preference”, Journal of Services Marketing, Vol. 28 No. 3, pp. 181-194.

McDonald, L.M. and Rundle, T.S. (2008), "Corporate social responsibility and bank customer satisfaction: a research agenda", International Journal of Bank Marketing, Vol. 26 No. 3, pp. 170-182.

MacKenzie, S.B. and Lutz, R.J. (1989), "An empirical examination of the structural antecedents of attitude toward the ad in an advertising pretesting context", Journal of Marketing, Vol. 53 No. 2, pp. 48-65. 
MacKenzie, S.B. and Podsakoff, P.M. (2012), "Common method bias in marketing: causes, mechanisms, and procedural remedies", Journal of Retailing, Vol. 88 No. 4, pp. 542-555.

Maignan, I. and Ferrell, O.C. (2004), "Corporate social responsibility and marketing: an integrative framework", Journal of the Academy of Marketing Science, Vol. 32 No. 1, pp. 3-19.

Marinkovic, V. and Obradovic, V. (2015), "Customers' emotional reactions in the banking industry", International Journal of Bank Marketing, Vol. 33 No. 3, pp. 243-260.

Martin, D., O'Neill, M., Hubbard, S. and Palmer, A. (2008), "The role of emotion in explaining consumer satisfaction and future behavioural intention”, Journal of Services Marketing, Vol. 22 No. 3, pp. 224-236.

Miles, P., Miles, G. and Cannon, A. (2012), "Linking servicescape to customer satisfaction: exploring the role of competitive strategy", International Journal of Operations and Production Management, Vol. 32 No. 7, pp. 772-795.

Moliner, T.M.A., Monferrer, T.D. and Estrada, G.M. (2018), “Consequences of customer engagement and customer self-brand connection”, Journal of Services Marketing, Vol. 32 No. 4, pp. 387-399.

Moliner, T.M.A., Monferrer, T.D. and Estrada, G.M. (2019), "Customer engagement, non-transactional behaviors and experience in services", International Journal of Bank Marketing, Vol. 37 No. 3, pp. 730-754.

Monferrer, D., Estrada, M., Fandos, J.C., Moliner, M.A. and Sánchez, J. (2016), "Service quality in bank during an economic crisis", International Journal of Bank Marketing, Vol. 34 No. 2, pp. 235-259.

Monferrer, T.D., Moliner, T.M.A. and Estrada, G.M. (2019), “Ambidexterity as a key factor in banks' performance: a marketing approach", Journal of Marketing Theory and Practice, Vol. 27 No. 2, pp. 227-250.

Nilsson, E. and Ballantyne, D. (2014), "Reexamining the place of servicescape in marketing: a service-dominant logic perspective", Journal of Services Marketing, Vol. 28 No. 4, pp. 374-379.

Nunnally, J.C. (1978), Psychometric Theory, 2nd ed., McGraw-Hill, New York, NY.

Oatley, K. and Johnson, L.P.N. (1987), "Towards a cognitive theory of emotions", Cognition and Emotion, Vol. 1 No. 1, pp. 29-50.

Ou, Y.C. and Verhoef, P.C. (2017), "The impact of positive and negative emotions on loyalty intentions and their interactions with customer equity drivers", Journal of Business Research, Vol. 80, pp. 106-115.

Pansari, A. and Kumar, V. (2017), "Customer engagement: the construct, antecedents, and consequences", Journal of the Academy of Marketing Science, Vol. 45 No. 3, pp. 294-311.

Parasuraman, A., Zeithaml, V.A. and Berry, L.L. (1988), "SERVQUAL: a multiple-item scale for measuring consumer perceptions of service quality", Journal of Retailing, Vol. 64 No. 1, pp. 12-40.

Pedersen, O.W. (2010), "Environmental principles and environmental justice", Environmental Law Review, Vol. 12 No. 1, pp. 26-49.

Pérez, R.A. and Rodríguez, D.B.I. (2012), "La imagen de Responsabilidad Social Corporativa en un contexto de crisis económica: El caso del sector financiero en España”, Universia Business Review, Vol. 2012 No. 33, pp. 14-29.

Podsakoff, P., MacKenzie, S.B., Lee, J.Y. and Podsakoff, N.P. (2003), "Common method biases in behavioral research: a critical review of the literature and recommended remedies", Journal of Applied Psychology, Vol. 88 No. 5, pp. 879-903.

Podsakoff, P.M. and Organ, D.W. (1986), "Self-reports in organizational research: problems and prospects", Journal of Management, Vol. 12 No. 4, pp. 531-544.

Rajaobelina, L. and Bergeron, J. (2009), "Antecedents and consequences of buyer-seller relationship quality in the financial services industry”, International Journal of Bank Marketing, Vol. 27 No. 5, pp. 359-80.

Richardson, H.A., Simmering, M.J. and Sturman, M.C. (2009), "A tale of three perspectives: examining post hoc statistical techniques for detection and correction of common method variance", Organizational Research Methods, Vol. 14 No. 4, pp. 762-800.
Service quality in a post-crisis context 
IJBM 38,1

Rust, R.T. and Oliver, R.L. (1994), "Service quality: insights and managerial implications from the frontier", in Rust, R.T. and Oliver, R.L. (Eds), Service Quality: New Directions in Theory and Practice, Sage Publications, Thousand Oaks, CA, pp. 1-19.

Sayani, H. (2015), "Customer satisfaction and loyalty in the United Arab Emirates banking industry", International Journal of Bank Marketing, Vol. 33 No. 3, pp. 351-375.

Schumacker, R.E. and Lomax, R.G. (1996), A Beginner's Guide to Structural Equation Modelling, Lawrence Erlbaum Associates, Mahwah, NJ.

Schwartz, M.S. and Carroll, A.B. (2003), "Corporate social responsibility: a three-domain approach", Business Ethics Quarterly, Vol. 13 No. 4, pp. 503-530.

Steenkamp, J.B.E.M. and van Trijp, H.C.M. (1991), "The use of lisrel in validating marketing constructs”, International Journal of Research in Marketing, Vol. 8 No. 4, pp. 283-299.

Strandberg, C., Wahlberg, O. and Öhman, P. (2012), "Challenges in serving the mass affluent segment: bank customer perceptions of service quality", Managing Service Quality, Vol. 22 No. 4, pp. 359-385.

Tsoukatos, E. and Mastrojianni, E. (2010), "Key determinants of service quality in retail banking", EuroMed Journal of Business, Vol. 5 No. 1, pp. 85-100.

Turker, D. (2009), "Measuring corporate social responsibility: a scale development study", Journal of Business Ethics, Vol. 85 No. 4, pp. 411-427.

Ullman, J.B. (2001), "Structural equation modelling”, in Tabachnick, B.G. and Fidell, L.S. (Eds), Using Multivariate Statistics, 4th ed., Allyn \& Bacon, Needham Heights, MA, pp. 653-771.

van Doorn, J., Lemon, K.N., Mittal, V., Nass, S., Pick, D., Pirner, P. and Verhoef, P.C. (2010), "Customer engagement behavior: theoretical foundations and research directions", Journal of Service Research, Vol. 13 No. 3, pp. 253-266.

Velicer, W.F. and Jackson, D.N. (1990), "Component analysis versus common factor analysis: some further observations", Multivariate Behavioral Research, Vol. 25 No. 1, pp. 97-114.

Wahlberg, O., Öhman, P. and Strandberg, C. (2016), "How personal advisors make a difference in serving 'almost rich' bank customers”, International Journal of Bank Marketing, Vol. 34 No. 6, pp. 904-923.

Wang, H., Kim, K.H., Ko, E. and Liu, H. (2016), "Relationship between service quality and customer equity in traditional markets", Journal of Business Research, Vol. 69 No. 9, pp. 3827-3834.

Williams, L.J., Hartman, N. and Cavazotte, F. (2010), "Method variance and marker variables: a review and comprehensive CFA marker technique", Organizational Research Methods, Vol. 13 No. 3, pp. 477-514.

Ye, J., Marinova, D. and Singh, J. (2007), "Strategic change implementation and performance loss in the front lines", Journal of Marketing, Vol. 71 No. 4, pp. 156-171.

Zameer, H., Tara, A., Kausar, U. and Mohsin, A. (2015), "Impact of service quality, corporate image and customer satisfaction towards customers' perceived value in the banking sector in Pakistan", International Journal of Bank Marketing, Vol. 33 No. 4, pp. 442-456.

\section{Further reading}

Browne, M.W. and Cudeck, R. (1993), "Alternative ways of assessing model fit", in Bollen, K.A. and Long, J.S. (Eds), Testing Structural Equation Models, Sage, Beverly Hills, CA, pp. 136-162.

\section{Corresponding author}

Manuel Idrovo Arguello can be contacted at: idrovomanuel89@gmail.com

For instructions on how to order reprints of this article, please visit our website:

www.emeraldgrouppublishing.com/licensing/reprints.htm

Or contact us for further details: permissions@emeraldinsight.com 